\title{
Remote Sensing of Potential and Actual Daily Transpiration of Plant Canopies Based on Spectral Reflectance and Infrared Thermal Measurements - Concept with Preliminary Test -
}

\author{
Yoshio Inoue*, M. Susan Moran** and Paul J. Pinter JR.** \\ (*National Institute of Agro-Environmental Sciences, Tsukuba, Ibaraki, 305 Japan \\ (** U.S. Water Conservation Laboratory, 4331 E. Broadway Rd., Phoenix, AZ, 85040 USA
}

\begin{abstract}
A new concept for estimating potential and actual values of daily transpiration rate of vegetation canopies is presented along with results of an initial test. The method is based on a physical foundation of spectral radiation balance for a vegetation canopy, the key inputs to the model being the remotely sensed spectral reflectance and the surface temperature of the plant canopy. The radiation interception or absorptance is estimated more directly from remotely sensed spectral data than it is from the leaf area index. The potential daily transpiration is defined as a linear function of the absorbed solar radiation, which can be estimated using a linear relationship between the fraction absorptance of solar radiation and the remotely sensed Soil Adjusted Vegetation Index for the canopy. The actual daily transpiration rate is estimated by combining this concept with the Jackson-Idso Crop Water Stress Index, which also can be calculated from remotely sensed plant leaf temperatures measured by infrared thermometry. An initial demonstration with data sets from an alfalfa crop and a rangeland suggests that the method may give reasonable estimates of potential and actual values of daily transpiration rate over diverse vegetation area based on simple remote sensing measurements and basic meteorological parameters.

Key words: Infrared thermometry, Remote sensing, Spectral reflectance, Transpiration, Water stress.
\end{abstract}

\section{Introduction}

Yield and biomass production of plants have been reported to be correlated with the amount of canopy water use (Hanks, 1983; Howell, 1990). In fact, both $\mathrm{CO}_{2}$ and $\mathrm{H}_{2} \mathrm{O}$ exchange processes between plant leaves and the atmosphere are primarily regulated by stomatal aperture. Thus, effective water management is one of the most important issues in agricultural production, especially in arid and semi-arid regions. The more important the impact of global climate change and population growth become, the more important efficient water use will be at regional and global scales. Consequently, remote sensing techniques are expected to provide an effective method for estimating water consumption over wide areas of crop canopies as well as natural vegetation.

Recieved on July 6, 1993

Accepted on January 6, 1994
Although evapotranspiration (ET), i.e. the total value of evaporation from the soil surface and transpiration from plant leaves, has been estimated based on lysimeter measurements and energy balance models such as the Penman-method (Gates, 1980), it is essential to estimate transpiration separately from evapotranspiration for better understanding of water and energy exchange processes in the soil-plant-atmosphere continuum as well as for more efficient water use in plant production. However, few methods are available, for estimating the transpiration rate $(T r)$ of intact plants over wide areas (Inoue, 1990). Daily estimates of these parameters seem to be sufficient for such applications as crop diagnosis, yield prediction, management decision-making and ecological plant science. Our objective, thus, is to estimate the energy-limited potential values and actual values of daily transpiration rate $\left(\operatorname{Tr}_{p}\right.$ and $\left.T r_{a}\right)$ in vegetation canopies. In this paper, we 
present the new concept along with the results of preliminary tests. The method is based on a physical foundation of spectral radiation balance for the vegetation, the key inputs to the method being the remotely sensed spectral vegetation index and the surface temperature of plants.

\section{Concept and Model}

\subsection{Basic concept}

Although the term "potential" transpiration is often used, it is not well-defined, because it is determined by the interaction of the physiological status of plants and physical environmental factors. Even flooded rice plants, for example, can not always transpire at the "potential" rate. Plant water status is usually closely related to the soil water status. Nevertheless, we can easily imagine some extreme situations such as potentially transpiring plants on a completely dry soil-surface or physiologically depressed (i.e., decreased transpiration) ones over a completely wet soil-surface. These situations can occur not only in imaginary extreme conditions but also in actual field conditions.

Thus, it may be better to define a meteorological "potential" transpiration based on the available energy for vaporization at the plant leaves; that is, healthy plants without water shortage are transpiring at the potential rate which is mainly regulated by the available energy. This energy limited transpiration has often been estimated by a linear function of absorbed solar radiation (Makkink, 1957) or absorbed net radiation (Priestley and Taylor, 1972). Such "radiation methods" have been widely used for the estimation of canopy transpiration (Brutsaert, 1982). In fact, Sakuratani (1987) reported a close correlation between absorbed solar radiation and transpiration of wellwatered soybean plants.

The total radiation energy absorbed is a function of the incoming solar radiation $(R s)$ and the interception-ability of the canopy. The intercepted solar radiation (IRS) has been analyzed as an exponential function of leaf area index $(L A I)$ using the relationship (Monsi and Saeki, 1953),

$$
I R s=R s[1-\exp (-k L A I)]
$$

where $k$ is an extinction coefficient that is a function of both canopy architecture and spectral features of leaf sections. Also, the intercepted or absorbed photosynthetically active radiation $(A P A R)$ has been related to $L A I$ in a similar manner, $A P A R=P A R[1-\exp (-k L A I)]$ (Asrar et al., 1984), where $P A R$ is the incident photosynthetically active radiation.

On the other hand, a number of papers have reported a close relationship between $L A I$ or biomass and remotely sensed spectral reflectance values such as vegetation indices (VI;e.g., Wiegand et al., 1991). From a theoretical point of view, however, the radiation balance of a canopy may be estimated more directly from remotely sensed spectral data than from the leaf area index, because effects of other factors such as canopy architecture, the spectral signature of the leaf and viewing/ illumination geometry can be included in the spectral measurements. In fact, $A P A R$ was shown to be well estimated by spectral reflectance measurements (Asrar et al., 1984; Gallo et al., 1985; Inoue et al., 1991). Furthermore, Pinter (1993) showed that the relationship between fraction $A P A R(f A P A R)$ and spectral indices derived from reflectance measurements was independent of solar zenith angle or time of day, though the actual values of these parameters varied with time of the day. His results suggest that the use of multispectral vegetation indices (such as $S A V I$, soil adjusted vegetation index) to estimate the proportion of incident solar energy absorbed by a plant community is promising and has biologically significant meaning.

On the basis of the above consideration, we assume that $[1-\exp (-k L A I)]$ can be expressed as a linear function of the spectral vegetation index, skipping the estimation of both $k$ and $L A I$ values; that is,

$$
f A P A R=1-\exp (-k L A I) \propto V I
$$

Considering the radiation balance of a canopy, one can define the radiation absorbed by the canopy $(A R s)$ as,

$$
A R s=R s\left[1-r-\left(1-r_{0}\right) \exp (-k L A I)\right]
$$

where $r$ and $r_{0}$ are the reflectances of the canopy and soil, respectively. The value of $r$ was found to be related to the reflectance $r_{f}$ of a full-cover canopy and $r_{0}$ of bare soil, respectively,

$$
r=r_{f}-\left(r_{f}-r_{0}\right) \exp \left(-k^{\prime} L A I\right)
$$

where $k^{\prime}$ is a constant (ET research group, 1967). The value of $k^{\prime}$ was found to be similar to $k$. Moreover, the effects of both $r_{0} \exp (-k L A I)$ and 
$r_{0} \exp \left(-k^{\prime} L A I\right)$ are small, and the difference between these two terms is negligible. Thus, we can obtain the following equation by substituting Eq. 4 into Eq. 3,

$$
\begin{aligned}
A R s & =R s\left(1-r_{f}\right)[1-\exp (-k L A I)] \\
& =R s\left(1-r_{f}\right) \text { fAPAR } \\
& =R s \alpha^{\prime} S A V I
\end{aligned}
$$

where $\alpha^{\prime}$ is an accumulated proportionality constant. SAVI is the Soil Adjusted Vegetation Index defined as,

$$
S A V I=\left[\left(\rho_{\mathrm{NIR}}-\rho_{\mathrm{RED}}\right) /\left(\rho_{\mathrm{NIR}}+\rho_{\mathrm{RED}}+L\right)\right](1+L)
$$

where $\rho_{\mathrm{NIR}}$ and $\rho_{\mathrm{RED}}$ are the near-infrared and red reflectance factors, respectively, and $L$ is assumed to be 0.5 for a wide variety of $L A I$ values (Heute, 1988). Since we assume that the "potential" daily transpiration $T r_{p}$ is proportional to the $A R s /$ $\lambda$, it is expressed as,

$$
\operatorname{Tr}_{p}=\alpha S A V I R s
$$

where $\alpha$ is a coefficient including $\alpha^{\prime}$ and the latent heat of vaporization $\lambda$.

Next, we can estimate the "actual" daily transpiration rate $\left(\operatorname{Tr}_{a}\right)$ by combining this concept with the Jackson-Idso Crop Water Stress Index (CWSI; Idso et al., 1981; Jackson et al., 1981). The CWSI is proposed as an indicator of crop water status, and $C W S I$ values can be calculated based on canopy and air temperatures $\left(t_{c}\right.$ and $\left.t_{a}\right)$ and vapor pressure deficit (VPD). The CWSI for plants is defined theoretically as $C W S I=1-T r_{a} /$ $\operatorname{Tr}_{p}$, which is discussed in detail in the next section. Therefore, $\operatorname{Tr}_{a}$ can finally be estimated by,

$$
\operatorname{Tr}_{a}=\alpha S A V I R s(1-C W S I)
$$

based on the combination of remotely sensed spectral and infrared thermal measurements with sound physical foundation.

\subsection{Evaluation of $C W S I$}

The crop water stress index has proved useful for estimating the stress status of crop canopies (Idso et al., 1981; Jackson et al., 1981). A number of scientists have examined the CWSI and/or related methods for various crops over a wide range of environmental conditions and confirmed the effectiveness of such methods (e.g., Diaz et al., 1983; Heilman et al., 1987; Hattendorf et al., 1988). The usefulness and limitations of the CWSI are summarized by Jackson (1982), O'Toole et al. (1984), Hatfield (1990) and Choudhury (1989). According to Jackson (1981), CWSI was ex- pressed empirically as

$$
C W S I=\left(t_{c}-t_{c l}\right) /\left(t_{c u}-t_{c l}\right)
$$

where $t_{c u}$ is the maximum crop temperature at which no transpiration occurs, and $t_{c l}$ is the lower limit of crop temperature when the plants are potentially transpiring. Also, Jackson (1982) showed the theoretical background of the index based on the plant canopy-air relationship,

$$
\begin{aligned}
C W S I & =1-E T / E T_{p} \\
& =\left[\left(r\left(1+r_{c} / r_{a}-r\right)-r^{*}\right] /\left[\Delta+r\left(1+r_{a} / r_{c}\right)\right]\right.
\end{aligned}
$$

where $r_{c} / r_{a}=\left[r r_{a} R n_{c} /(C v)-\left(t_{c}-t_{a}\right)(\gamma+\Delta)-V P D\right]$ $/\left[r\left\{\left(t_{c}-t_{a}\right)-r_{a} R n_{c} /(C v)\right\}\right], \quad E T$ and $E T_{p}$ are the actual and potential evapotranspiration, $r$ is the psychrometric constant $\left(\mathrm{kPa}^{\circ} \mathrm{C}^{-1}\right), r^{*}$ is $r(1-$ $r_{c p}\left(r_{a}\right), r_{c p}$ and $r_{a}$ are the canopy resistance at the potential transpiration and the aerodynamic resistance, respectively, $\Delta$ is the slope of the saturated vapor pressure versus temperature curve $\left(\mathrm{kPa}^{\circ} \mathrm{C}^{-1}\right)$, $V P D$ is the vapor pressure deficit $(\mathrm{kPa})$, and $C v$ is the volumetric heat capacity of air $\left(\mathrm{J} \mathrm{m}^{-3}{ }^{\circ} \mathrm{C}^{-1}\right)$. Although $C W S I$ is expressed as $1-E T / E T_{p}$ in Eq. 10 , as Jackson (1982) warned, "it is important that the soil background not appear in the field of view of the infrared thermometer. Plant temperature only is desirable for the calculation of CWSI", the CWSI is calculated with an assumption that the surface is full-vegetation canopy. In other words, $C W S I$ can be expressed as $1-T r / T r_{p}$ in his context because the difference between $E T$ and $T r$ is minor for full-vegetation canopy. This is the main reason why application of the $C W S I$ has been hampered by the difficulty of measuring foliage temperature in partially-vegetated fields.

All input parameters necessary for CWSI can be computed using theoretical and/or empirical equations. As for the aerodynamic resistance which is one of the most important parameters in the above equation, a variety of published equations are available, ranging from simple (a function of windspeed $(u)$ only; e.g., Thom and Oliver, 1977) to quite rigorous (accounting for atmospheric stability and based on values of $u$, the surface and air temperature difference, surface "aerodynamic" roughness and other parameters; e.g., Kustas et al., 1989).

Further improvements of the index have been suggested for extending its applicability or for simplification (Clawson et al., 1989; Moran et al., 
1993).

\section{Data used for an initial test}

Two data sets used for an initial test of the method were from 1) an experiment in an alfalfa field at the U.S. Water Conservation Laboratory, Phoenix in 1985, and 2) another experiment in a semi-arid rangeland (Walnut Gulch Experimental Watershed) near Tombstone, Arizona in 1992. Methods and results from these measurements have been presented by Moran et al. $(1989,1993)$ and Kustas et al. (1991). Because actual transpiration measurements were not made in either the alfalfa or the rangeland experiments, the results from these comparisons do not validate but simply demonstrate the feasibility of our new concept. Estimates of daily transpiration can be compared with measurements of evapotranspiration to determine if the results are reasonable.

\subsection{Alfalfa experiment}

An $80 \times 60 \mathrm{~m}$ field was segmented into 18 plots in which alfalfa seeds (Medicago sativa, L.) were broadcast planted. The field was tended for one year, during which all 18 plots were irrigated uniformly. After one year's growth, some of 18 plots were flood irrigated at different intervals to vary levels of water stress and biomass. Four different irrigation regimes were applied to the alfalfa: the WET treatment recived two irrigations between cuttings; the EARLY treatment was irrigated once, immediately after harvest; the LATE treatment received water midway between cuttings, and the DRY treatment received no supplementary water by irrigation from one harvest until the next. The growth interval between harvests ranged from 3.5 weeks in the summer to 9 weeks during winter.

Crop canopy reflectances were measured using handheld rediometers (Exotech MSS and Barnes MMR*) with a $15^{\circ}$ field-of-view. The radiometers had the similar spectral bands to those of the Landsat Multispectral Scanner (MSS) and the Landsat Thematic Mapper, respectively. Multispectral observations were made several times a week at a morning time period. MMR data were acquired at 10:30 Mountain Standard Time to

\footnotetext{
*Trade names and company names are given for the benefit of the reader and do not imply endorsement of the product or company by the organizations with which the authors are affiliated.
}

coincide with the time of the Landsat overpass. Canopy surface temperatures were measured with an infrared thermometer (Everest*). Aboveground dry biomass was determined from four cuttings of $0.25 \mathrm{~m}^{2}$ in each treatment. Evapotranspiration rates were measured with $1 \mathrm{~m} \times 1 \mathrm{~m}$ $x 1.5 \mathrm{~m}$ lysimeters in three different plots. Throughout the experiment, the lysimeters were irrigated by hand at the same times and with the same amounts of water as the surrounding plots. A multitude of other meteorological parameters were monitored every $30 \mathrm{~min}$. during the experiment, including air temperature, wind speed, reflected and incoming solar radiation, canopy and soil temperatures, and vapor pressure.

\subsection{Rangeland experiment}

The Walnut Gulch '92 (WG '92) experiment was conducted in a semi arid rangeland over an entire growing season from April to November 1992, with a variety of soil moisture conditions and vegetation densities. The size of the main study site was about $50 \mathrm{~km}^{2}$, at the eight locations of which both general meteorological conditions and surface energy balance were measured. Data used here were from a grassland site (Kendall). The spectral data used here are based on ground-based measurements using yoke-mounted Exotech MSS and Barnes MMR radiometers and infrared thermometers (Everest). On five line transects of $30 \mathrm{~m}$ each, vegetation parameters such as percent cover, average plant height and volume by species, total $L A I$ and biomass, litter standing and lying, and plant water content were measured. Evapotranspiration flux densities were measured with eddycorrelation apparatus.

\section{Results and discussion}

\subsection{Alfalfa experiment-Single harvest period}

This initial analysis was limited to one harvest period from the day of year (DOY) 154 to 184 , when reflectance and temperature measurements were made nearly every day and clear-sky conditions persisted for 28 of 30 days. During this period, two lysimeters were subjected to EARLY and WET irrigation treatments, respectively. Results presented here are for spectral and meteorological measurements centered on 10:30 each day.

The values of $\alpha$ in Eq. 7 was computed based 
on evaluation of the relation between $S A V I$ at $10: 30, R s$ and $E T_{a}$ (measured using lysimeter) for full-cover and well-watered canopies on clear days. Under these circumstances, we can assume that $\operatorname{Tr}_{p}=E T_{a}$. The $\alpha$ value for alfalfa was computed to be 1.50. Based on this value of $\alpha$ and the CWSI calculated using surface temperature measurements, the values of $\operatorname{Tr}_{a}$ were computed for all treatment plots. The values of $T r_{a}$ for the EARLY and WET plots correspond as expected with the $E T_{a}$ values measured by lysimeters in each plot (Fig. 1). That is, $\operatorname{Tr}_{a}$ is substantially lower than $E T_{a}$ when vegetation density is low (DOY 158170), and $T r_{a}$ is nearly equal to $E T_{a}$ for full-cover canopy. Furthermore, the trend of decreasing $E T_{a}$ with time in the EARLY treatment is reflected in the $\operatorname{Tr}_{a}$ estimates. The extremely low $E T_{a}$ values observed in the EARLY plot for DOY 179-183 was caused presumably by some unusual condition of the lysimeter.
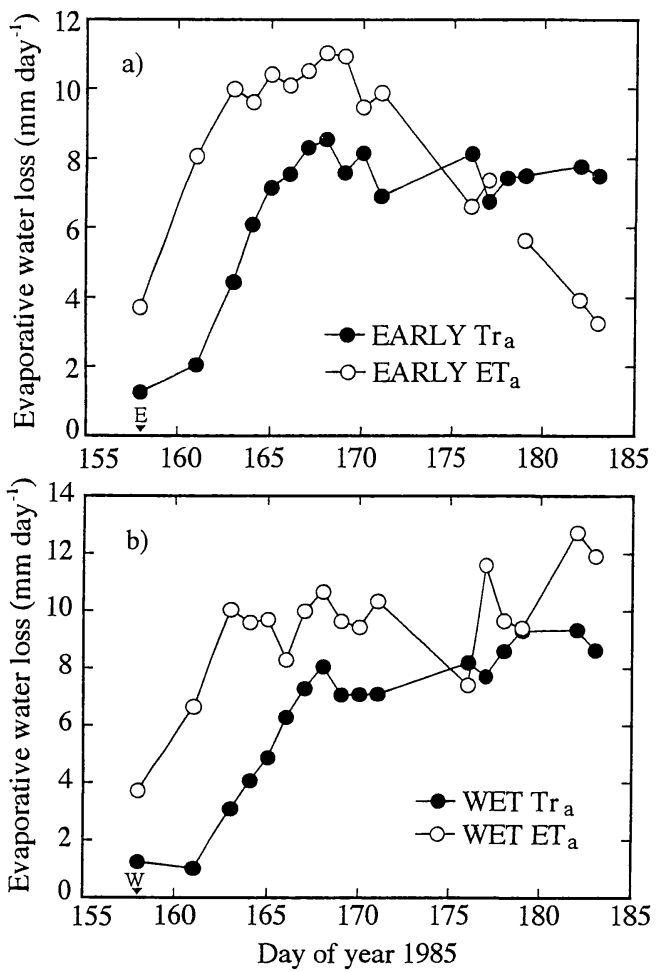

Fig. 1. Comparison of estimated $\operatorname{Tr}_{a}$ and measured $E T_{a}$ for the EARLY and WET alfalfa treatment plots. Symbols $\boldsymbol{\nabla}$ with plots' initials indicate the dates of irrigation in each plot.
Estimates of $\operatorname{Tr}_{a}$ for the eight treatments (two replicates of WET, EARLY, LATE and DRY) were also reasonable (Fig. 2). That is, the $T r_{a}$ in the WET plots remained high throughout the harvest cycle; $\operatorname{Tr}_{a}$ in the EARLY plots was similar to the WET plots early in the cycle and decreased late in the cycle; the $\operatorname{Tr}_{a}$ in the LATE plots was low until the late irrigation; and in the DRY plots it remained lower than all others throughout the harvest cycle.

Considering Eq. 8, it is apparent that this approach for estimation of $\operatorname{Tr}_{a}$ accounts for both differences in vegetation density and stress response of the plants. As such, it is informative to look at both biomass and CWSI in relation to estimates of $\operatorname{Tr}_{a}$. For example, Fig. 3 shows a pair of data from WET and EARLY treatments, both of which have similar biomass values. The transpiration of the WET plot was lower than that of the EARLY plot for the first half of the growth cycle
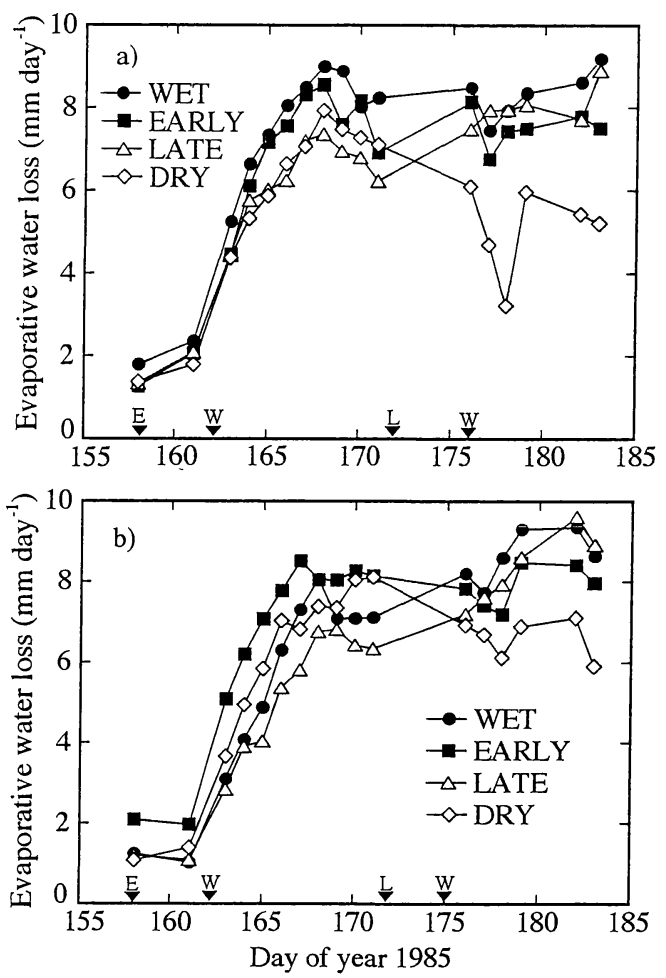

Fig. 2. Comparison of estimated $\operatorname{Tr}_{a}$ values for the two replicates of WET, EARLY, LATE and DRY alfalfa treatment plots. Symbols $\boldsymbol{\nabla}$ with plots' initials indicate the dates of irrigation in each plot. 

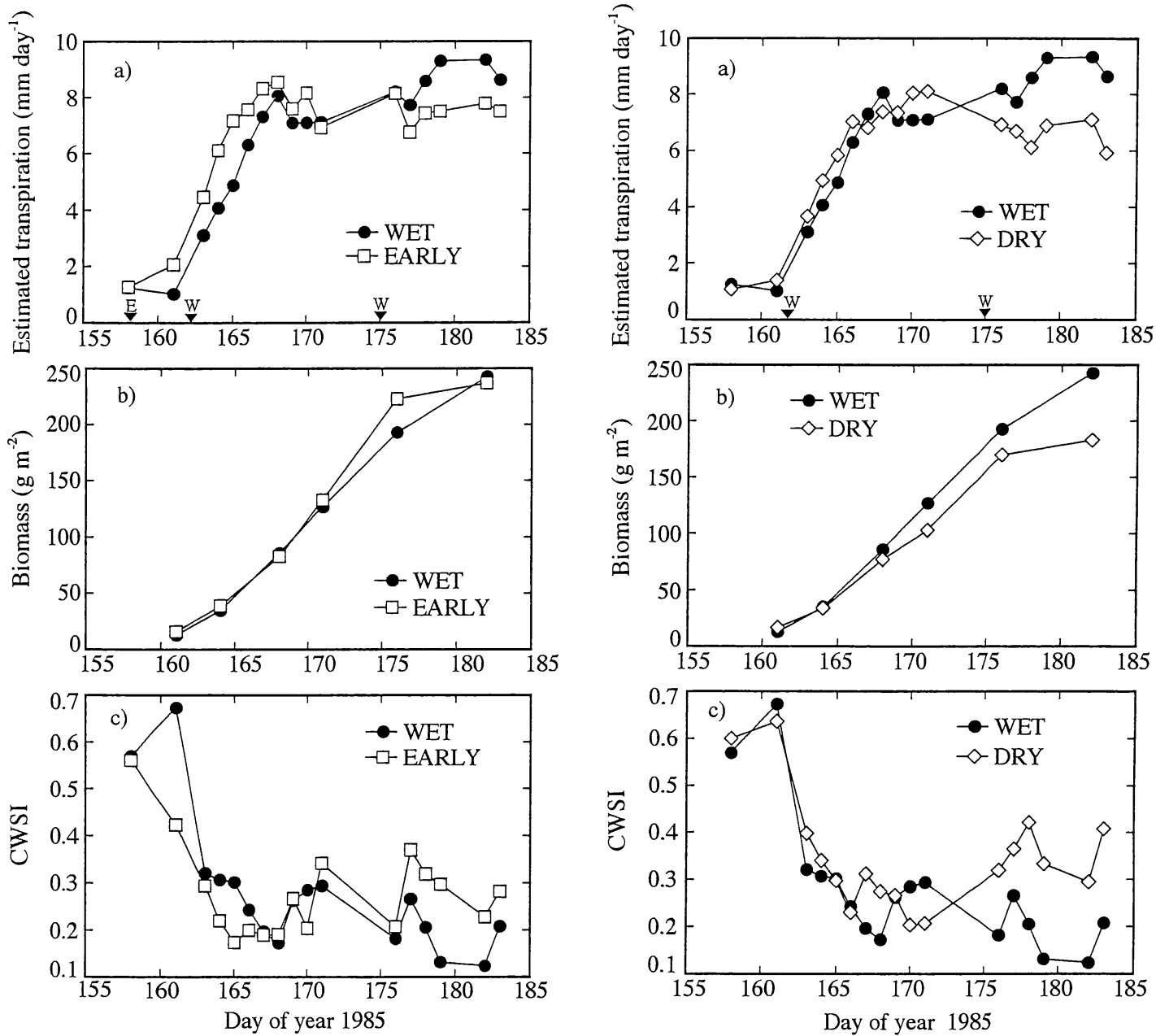

Fig. 3. For WET and EARLY treatments over a single alfalfa harvest period, a) estimates of daily transpiration $\left(T_{a}\right)$ and measurements of b) biomass and c) CWSI.

and higher during the second half (Fig. 3a); yet the biomass measurements taken in the two plots over the growth cycle were nearly identical (Fig. 3b). The differences in $\operatorname{Tr}_{a}$ between the two plots were due to corresponding differences in CWSI (Fig. 3c). A similar example presenting differences in both biomass and CWSI for WET and DRY plots is shown in Fig. 4.

\subsection{Alfalfa experiment-Data from three hervest periods}

The analysis presented here covers three harvest periods from DOY 40 to 151 . Three lysimeters were subjected to EARLY treatment during the period from DOY 40-90 (a), from DOY 91-130

Fig. 4. For WET and DRY treatments over a single alfalfa harvest period, a) estimates of daily transpiration $\left(\operatorname{Tr}_{a}\right)$ and measurements of $\mathrm{b}$ ) biomass and c) CWSI.

(b), and from DOY 131-154 (c), respecitively. The other two lysimeters were treated as WET plots in each growth cycle. Results here are based on the spectral and meteorological measurements centered on 10:30 each day. The value of $\alpha$ in Eq. 8 was assumed to be 1.5 , based on the analysis in section 4.1. The $r_{a}$ value was computed with the simple formula (Thom and Oliver, 1977), accounting for variations in plant height and windspeed. Based on this value of $\alpha$ and the CWSI computed using Eq. 10, $\operatorname{Tr}_{a}$ values were calculated for the WET, EARLY, LATE and DRY plots, and each lysimeter plot ( $a, b$ and $c$ ) regardless of treatment. 
The values of $\operatorname{Tr}_{a}$ for the three lysimeter plots correspond as expected with the $E T_{a}$ values measured by lysimeters in each plot (Fig. 5). That is, $\operatorname{Tr}_{a}$ was substantially lower than $E T_{a}$ when vegetation density was low (after harvest), and $T r_{a}$ was nearly equal to $E T_{a}$ for full-cover canopy. Similar to results presented in Fig. 4, the differences in transpiration rates between WET and DRY plots were directly correlated with biomass and/or stress differences (Fig. 6).

\subsection{Rangeland-Data from single growing season}

The test presented here was limited to a grassland site from DOY 114 to 290 , during the dry, monsoon and post-monsoon periods.
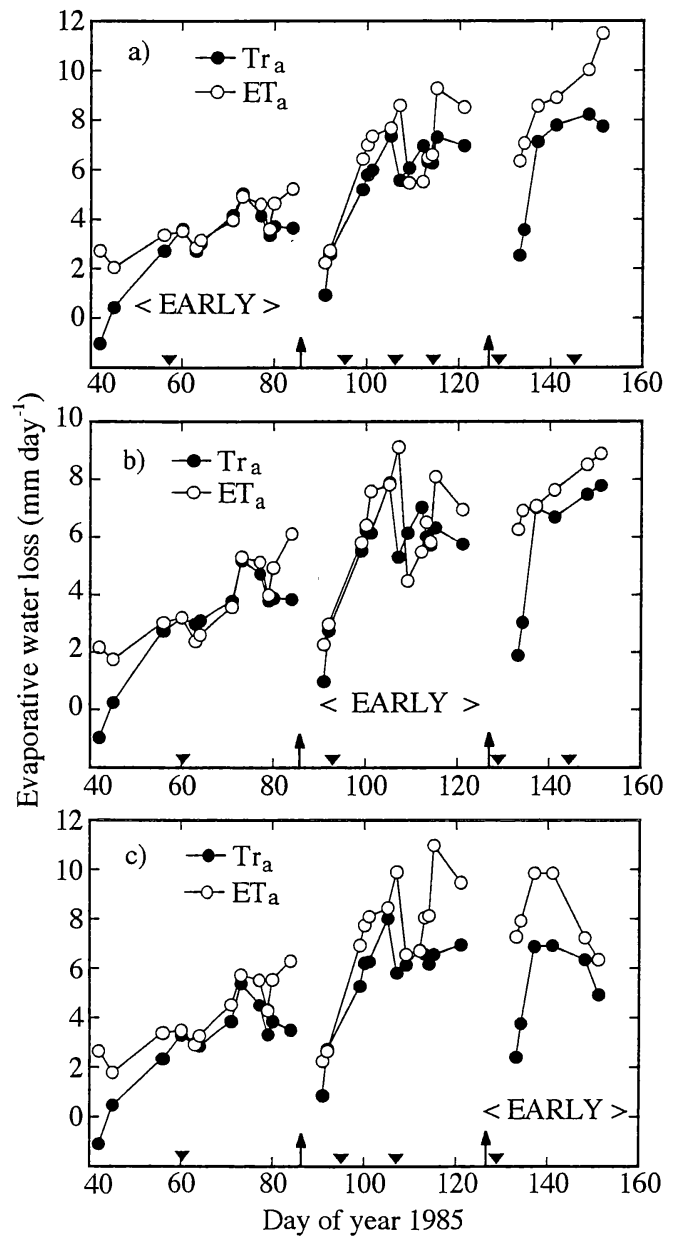

Fig. 5. For three alfalfa harvest periods, comparison of $\operatorname{Tr}_{a}$ in three differentially irrigated plots $(\mathrm{a}, \mathrm{b}, \mathrm{c})$ with actual daily $E T$ values $\left(E T_{a}\right)$ measured by lysimeters in each plot. Arrows and symbols $\boldsymbol{\nabla}$ indicate the dates of harvest and irrigation, respectively.
Deriving the $\alpha$ value for the WG'92 site was more difficult than for the alfalfa due to the lack of a well-watered, full-cover canopy at any time during the season. The $\alpha$ value was computed from data acquired on DOY 267. Based on soil temperature measurements made at the site, it was apparent that the soil surface was very dry. Since the vegetation was still relatively lush, we assumed that $E T_{a}$ was equal to $\operatorname{Tr}_{a}$ on this day. Thus, $\alpha$ was calculated using the spectral vegetation index $S A V I$ measured at 10:30 and $E T_{a}$ computed from eddy-correlation measurements on site. The $\alpha$ estimate for WG ' 92 was 1.47 , which was close to the $\alpha$ value for the alfalfa crop. For most of the
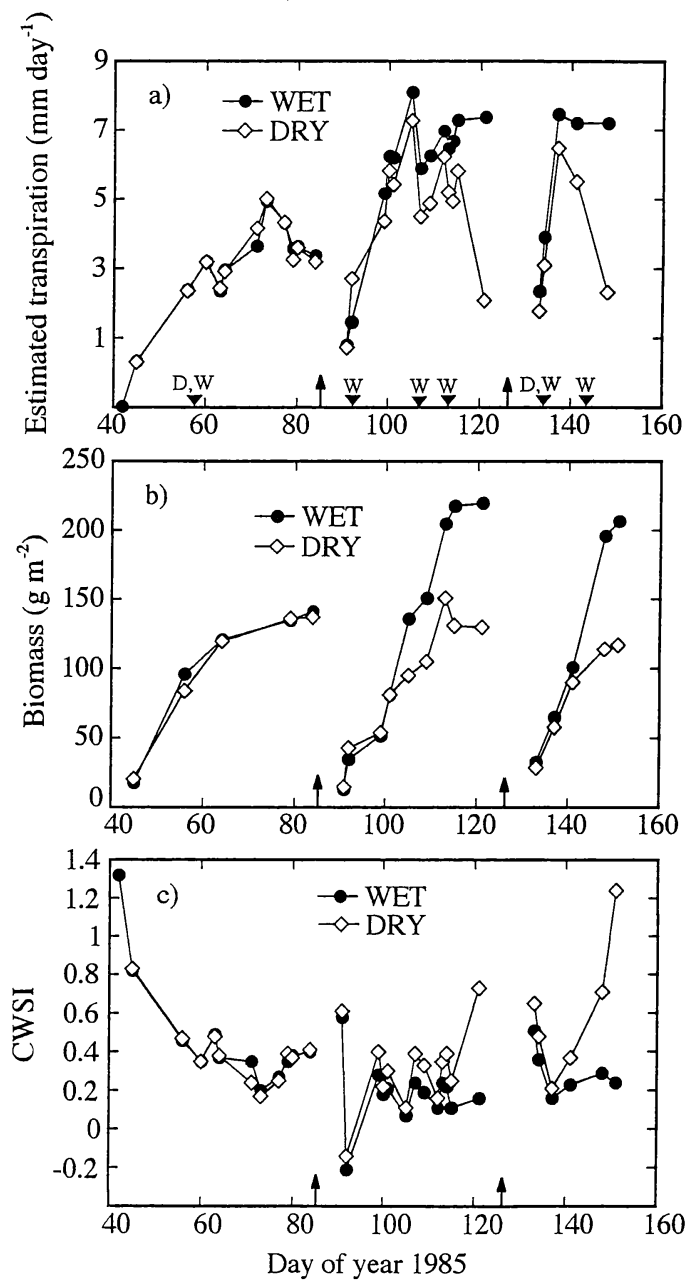

Fig. 6. For WET and DRY treatments over three alfalfa harvest periods, a) estimates of $\operatorname{Tr}_{a}$ and measurements of b) biomass and c) CWSI. Arrows and symbols $\boldsymbol{\nabla}$ indicate the dates of harvest and irrigation, respectively. 
growing season, the test site was characterized by large expanses of hot, dry soil with sparse vegetation; thus, an equation accounting for the additional resistance induced by the exposed soil as a function of windspeed and surface temperature (Kustas et al., 1989) was introduced for the estimation of $r_{a}$ (Fig. 7b).

Values of $\operatorname{Tr}_{a}, \operatorname{Tr}_{p}$ and $E T_{a}$ for all measurement days at the site were compared (Fig. 7). Two different estimates of aerodynamic resistance $r_{a}$ were used for the calculation of these parameters. It is apparent that the water stress was overestimated using $r_{a}$ without excess resistance and was more reasonable when the excess resistance was included. As expected, the $\operatorname{Tr}_{a}$ values were lower than $E T_{a}$ values in nearly all cases. The $\operatorname{Tr}_{p}$ values were also lower than $E T_{a}$, especially in the early growing season with lower vegetation amount. However, it is difficult to make any conclusions about the feasibility of the application to the
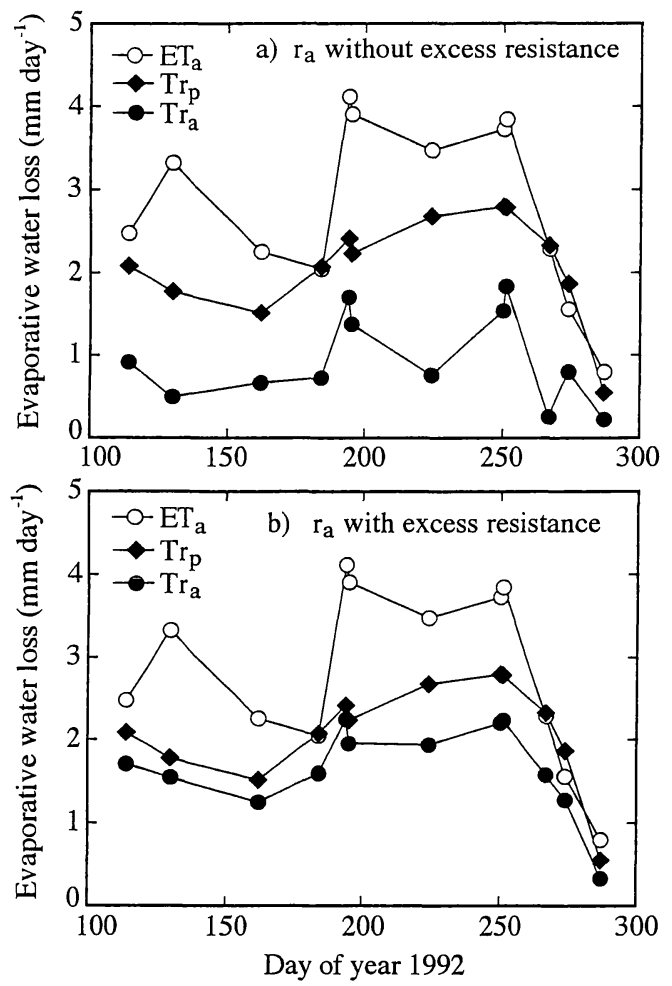

Fig. 7. Comparison of estimated values of potential and actual daily transpiration $\left(T r_{p}\right.$ and $\left.T r_{a}\right)$ with measured values of $E T_{a}$ at Walnut Gulch site. $C W S I$ was calculated using two estimates of aerodynamic resistance $r_{a}$; a) without excess resistance, and b) with excess resistance. rangeland site due to the questionable methods of deriving $\alpha$. It may be possible to derive $\alpha$ in a more justifiable manner using simultaneous measurements of $f A P A R$, albedo and spectral reflectances made by Daughtry during 1990 at WG site (personal communication, 1993).

\subsection{Concluding remarks}

We have presented a new concept for evaluating the potential and actual daily transpiration from vegetation based on remote sensing. On the basis of the initial results presented here and the technique's sound theoretical foundation, it is likely that this approach will be successful for evaluating potential and actual daily transpiration.

Several points require further investigation. 1) Behavior of the coefficient $\alpha$ will have to be examined in detail from experimental and theoretical points of view, because it may not always be consistent for various crops and sites. This $\alpha$ value is, by definition, determined as a function of fullcover reflectance and the slope of the $f A P A R$ and $S A V I$ relation as long as the proportionality between the absorbed solar radiation and the "potential" transpiration is assumed. From a practical point of view, nevertheless, both the full-cover reflectance and the slope are not expected to vary much for most crop canopies, and that is why $\alpha$ values for alfalfa and rangeland were similar (1.5 and 1.47 , respectively). 2) Several questions related to the estimation of $C W S I$ values for sparsely-vegetated sites or immature crops still need to be answered; a) Which formulation should be used to estimate $r_{a}$ in computation of $E T_{p}$ and $C W S I$ ?, b) How can we calculate a $C W S I$ value using $t_{s}$ (composite surface temperature) rather than $t_{c}$.(plant canopy temperature) ?, or how can we derive $t_{c}$ from $t_{s}$ ? It is possible that the new stress index devised by Moran et al. (1994) may provide a good solution for such questions. Also, high-resolution infrared thermal imagery will be useful, providing pixel-by-pixel temperatures over the area of soil and plant mixture (Inoue, 1990). We will be able to replace the present $C W S I$ by future improved stress indices. 3) The estimates of $\operatorname{Tr}_{p}$ and $\operatorname{Tr}_{a}$ values should be compared with "true" values directly measured using the stem flow gauge. Since measurements of $\operatorname{Tr}_{a}$ were not available in either the alfalfa or rangeland experiments, we used, instead, $E T_{a}$ values in the well- 
watered full-cover canopies. Therefore, these results represent simply a demonstration, not a verification, of the approach. New experiments in which transpiration will be measured directly with stem-flow gauges (Sakuratani, 1984) will be conducted for further examination of the concept.

The potential and actual values of daily transpiration rate may be estimated over wide vegetation areas with simple remote sensing measurements and basic meteorological parameters. The method may also provide information on biomass and stress status, because it accounts for the differences in both vegetation density and stress response of the plant canopy.

\section{Acknowledgments}

We would like to thank Dr. T. Sakuratani, NARC for helpful suggestions and careful review of the manuscript. We also acknowledge valuable discussions with Prof. T. Horie, Kyoto University.

\section{Reference}

Asrar, G., Hipps, L. E. and Kanemasu, E. T., 1984: Estimating absorbed photosynthetic radiation and leaf area index from spectral reflectance in wheat. Agron. J., 76, 300-306.

Brutsaert, W. H., 1982: Evaporation into the atomosphere. D. Reidel Publishing Company, Dordrecht, Holland, pp. 299.

Choudhury, B. J., 1989: Estimating evaporation and carbon assimilation using infrared temperature data: Vistas in modeling. Theory and applications of optical remote sensing (ed. Asrar, G.), John Wiley and Sons, New York, p. 628690.

Clawson, K. L., Jackson, R. D. and Pinter Jr., P. J., 1989: Evaluating plant water stress with canopy temperature differences. Agron. J., 81, 858863.

Diaz, R. A., Matthias, A. D. and Hanks, R. J., 1983: Evapotranspiration and yield estimation of spring wheat from canopy temperature. Agron. $J ., 75,805-810$.

ET research group, 1967: Radiation balance of paddy field. J. Agric. Meteorol., 22, 97-102.

Gallo, K. P., Daughtry, C. S. T. and Bauer, M. E., 1985: Spectral estimates of absorbed photosynthetically active radiation in corn canopies. Remote Sens. Environ., 17, 221-232.

Gates, D. M., 1980: Biophysical Ecology, Springer-Verlag, New York, p. 307-344.

Hanks, R. J., 1983: Yield and water-use relationship: An overview. Limitations to efficient water use in crop production (ed. Tayler, H. M. et al.), Am. Soc. Agronomy, Madison, p. 393411.

Hatfield, J. L., 1990: Methods of estimating evapotranspiration. Irrigation of Agricultural Crops (ed. Stewart, B. A. and Nielsen, D. R.), Am. Soc. Agronomy, Madison, p. 435-474.

Hattendorf, M. J., Carlson, R. E., Halim, R. A. and Buxton, D. R., 1988: Crop water stress index and yield of water-deficit-stressed alfalfa. Agron. $J ., 80,871-875$.

Heilman, J. L., Heilman, W. E. and Moore, D. G., 1981: Remote sensing of canopy temperature at incomplete cover. Agron. J., 73, 403-406.

Heute, A. R., 1988: A soil adjusted vegetation index (SAVI). Remote Sens. Environ., 25, 295 -309 .

Howell, T. A., 1990: Relationship between crop production and transpiration, evapotranspiration and irrigation. Irrigation of Agricultural Crops (ed. Stewart, B. A. and Nielsen, D. R.), Am. Soc. Agronomy, Madison, p. 392-434.

Idso, S. B., Jackson, R. D., Pinter Jr., P. J., Reginato, R. J. and Hatfield, J. L., 1981: Normalizing the stress-degree days for environmental variability. Agric. Meteorol., 24, 45-55.

Inoue,.Y., Kimball, B. A., Jackson, R. J., Pinter, Jr., P. J. and Reginato, R. J., 1990: Remote estimation of leaf transpiration rate and stomatal resistance based on infrared thermometry. Agric. Forest Meteorol., 51, 21-33.

Inoue, Y., 1990: Remote detection of physiological depression in crop plants with infrared thermal imagery. Jpn. J. Crop Sci., 59, 762768.

Inoue, Y. and Iwasaki, K., 1991: Spectral estimation of radiation absorptance and leaf area index in corn canopies as affected by canopy architecture and growth stage. Jpn. J. Crop Sci., $60,578-580$.

Jackson, R. J., Idso, S. B., Reginato, R. J. and Pinter Jr., P. J., 1981: Canopy temperature as a crop water stress indicator. Water Resour. Res., 17, 1133-1138.

Jackson, R. J., 1982: Canopy temperature and crop water stress. Advances in Irrigation (ed. Hillel, D. I.), Academic Press, New York, p. 4385.

Kustas, W. P., Choudhury, B. J., Moran, M. S., Reginato, R. J., Jackson, R. J., Gay, L. W. and Weaver, H. L., 1989: Determination of sensible heat flux over sparse canopy using thermal infrared data. Agric. Forest Meteorol., 44, 197 $-216$.

Kustas, W. P., Goodrich, D. C., Moran, M. S., 1991: An interdisciplinary field study of the energy and water fluxes in the atmosphere- 
biosphere system over semiarid rangelands: Description and some preliminary results. Bull. of Amer. Meteorol. Soc., 72, 1683-1706.

Makkink, G. F., 1957: Ekzameno de la formulo de Penman. Netherl. J. Agric. Sci., 5, 290-305.

Monsi, M. and Saeki, T., 1953: Uber den Lichtfactor in den Pflanzengesellshaften und seine Bedeutung fur dir Stoffproduktion. Jpn. J. Bot., 14, 22-52.

Moran, M. S., Pinter Jr., P. J., Clothier, B. E. and Allen, S. G., 1989: Effects of water stress on the canopy architecture and spectral indices of irrigated alfalfa. Remote Sens. Environ., 29, 251-261.

Moran, M. S., Clarke, T. R., Inoue, Y. and Vidal, A., 1994: Estimating crop water deficit using the relationship between surface-air temperature and spectral vegetation index. Remote Sens. Environ., (submitted).

O'Toole, J. C., Turner, N. C., Namuco, O. P., Dingkuhn, M. and Gomez, A., 1984: Comparison of some crop water stress measurement methods. Crop Sci., 24, 1121-1128.

Pinter, Jr., P. J., 1993: Solar angle independence in the relationship between absorbed PAR and remotely sensed data for alfalfa. Remote Sens. Environ., 46, 19-25.

Priestley, C. H. B. and Taylor, R. J., 1972: On the assessment of surface heat flux and evaporation using large scale parameters. Monthly Weath. Rev., 100, 81-92.

Sakuratani, T., 1984: Improvement of the probe for measuring water flow rate in intact plants with the stem heat balance method. J. Agric. Meteorol., 40, 273-277.

Sakuratani, T., 1987: Studies on evapotranspiration from crops (2) Separate estimation of transpiration and evaporation from a soybean field without water shortage. J. Agric. Meteorol., 42, 309-317.

Thom, A. S. and Oliver, H. R., 1977: On Penman's equation for estimating regional evaporation. Q.J.R. Meteorol. Soc., 103, 345-357.

Wiegand, C. L., Richardson, A. J., Escobar, D. E. and Gerbermann, A. H., 1991: Vegetation indices and crop assessments. Remote Sens. Environ., 35, 105-119.

\section{反射スペクトルおよび熱赤外計測に基づく植生 からのポテンシャルな日蒸散量と実日蒸散量の リモートセンシング—理論と予備的検証} 井上吉雄*, M. Susan Moran ** and Paul J. Pinter JR.** $\left(\begin{array}{c}* \text { 農業環境技術研究所 } \\ { }^{* *} \text { U.S. Water Conservation Laboratory, USDA-ARS, USA }\end{array}\right)$

\section{要}

リモートセン゙シングによって植物個体群からの日蒸散 量のポテンシャルおよび実際の值を評価するための新し い方法論を提示し, 実測データによる予備的検討を行っ た。本方法は, 植物個体群のポテンシャルな蒸散量が主 に吸収放射量によって規定されており，かつ個体群の放 射吸収能は葉面積指数から求めるよりあ分光学的な遠隔 計測によってより直接的に評価できるとの考え方に基づい ている。すなわち本方法では, 遠隔計測される反射スペク トルから求めた植生指数 (SAVI) と日射量からポテンシ ヤルな蒸散量を求め, さらに, 熱赤外放射測温に基づく

\section{約}

ストレス指標 $(C W S I)$ を組み込むととによって，スト レス状態と実蒸散量を同時に評価する。各種の灌溉処理 を行ったアルファルファ固場，および自然草地において 測定した反射スペクトル計測, 赤外線放射測温, ライシ メータ, 渦相関法, および植物サンプリングによるデー 夕を用いた予備検証の結果, 本手法の概念に基づいて, 分光データと基本的な微気象データの計測情報から, 広 域にわたる植生のポテンシャルおよび実際の日蒸散量を 評価できる可能性が示唆された。

キーワード：蒸散, 熱赤外計測, 反射スペクトル, 水ストレス, リモートセンシング. 